\title{
LOS SANTIAGUISTAS DEL REINO DE MURCIA DURANTE LA OCUPACIÓN ARAGONESA (1296-1304)
}

\author{
Regina SAINZ DE LA MAZA LASOLI \\ Institución Milá y Fontanals. CSIC
}

La donación del reino de Murcia que el 21 de enero de 1296 hizo el infante Alfonso de la Cerda a Jaime II, a cambio de su ayuda para conseguir el trono castellano, fue el punto de partida para que el monarca aragonés hiciera realidad su deseo de ocupación de este reino, aprovechando la minoría de edad de Fernando IV de Castilla. Gran parte del territorio de Murcia quedó bajo poder de Aragón por espacio de ocho años, desde 1296 a 1304, por medio de una gesta que desde diferentes puntos de vista ha sido tratada por varios historiadores. Yo misma, en 1980, y a raíz del estudio que realicé sobre la Orden de Santiago en Aragón, me referí a un aspecto muy concreto de esta ocupación: el del devenir de las encomiendas santiaguistas de Murcia durante dicho periodo ${ }^{1}$. Hoy, 16 años después de aquel primer acercamiento al tema, he querido ocuparme nuevamente de él porque el hallazgo de varios documentos inéditos me ha permitido ampliarlo y estudiarlo en mayor profundidad.

Qué duda cabe, y eso es un hecho conocido, que el señorío de la Orden de Santiago en Murcia, después del de don Juan Manuel, constituía uno de los poderes más importantes que Jaime II debía atraer a su causa, si quería que la ocupación del reino fuese un éxito. Mi propósito en las páginas que siguen será el de analizar, por un lado,

1 R. SAINZ DE LA MAZA LASOLI, La Orden de Santiago en la Corona de Aragón. La Encomienda de Montalbán (1210 1327). Institución Fernando el Católico, Zaragoza, 1980, pp. 170-177. También hacen referencia a los santiaguistas de Murcia bajo este periodo J. TORRES FONTES y A.L. MOLINA MOLINA, Murcia Castellana en Historia de la región murciana, vol. III, Murcia, Ediciones Mediterráneo, 1981, pp. 380-387; M. RODRÍGUEZ LLOPIS, “La expansión territorial castellana sobre la cuenca del Segura (1235-1325)», Miscelánea Medieval Murciana, XII (1985), pp. 118-125; J.M. del ESTAL, Corpus documental del Reino de Murcia bajo la soberanía de Aragón (1296-1304), Alicante, Instituto de Estudios «Juan Gil Albert», 2 vols. 1985 y 1990. 
la política que desarrolló Jaime II para atraer este poder a su causa, y por otro, examinar la reacción y los cambios de comportamiento que tuvieron los santiaguistas de Murcia, ante el cambio que suponía el sometimiento a un nuevo señor.

\section{SUMISIÓN DE LAS ENCOMIENDAS DE RICOTE, CIEZA Y ALEDO}

Las encomiendas santiaguistas en el reino de Murcia se extendían sobre la cuenca del río Segura, y de todas ellas fueron las de Ricote, Cieza y Aledo, más cercanas a la frontera de Aragón, las que quedaron bajo la influencia de este reino, sirviendo, las más alejadas de Segura, Socovos y Moratalla, de límite a la expansión de Jaime II. Pero a todas el monarca pidió la sumisión a medida que efectuaba la ocupación del reino.

La adhesión de las encomiendas de Ricote, Cieza y Aledo a la causa de Aragón no se consiguió por conquista u ocupación militar, que fue la forma adoptada por Jaime II para someter las villas y castillos reales, sino a través de unas negociaciones, que se iniciaron a mediados de mayo de 1296, y para las cuales el monarca se sirvió de su consejero Ferrán Garcés de Rueda².

El primer paso en estas negociaciones lo dio Jaime II el 20 de mayo, es decir, al día siguiente de haber conseguido la capitulación de Murcia. Desde la misma capital, donde el monarca decidió reposar unos días, escribió a Fernando Pérez y a Juan Martínez, comendadores de Ricote y Cieza, respectivamente, anunciándoles la visita de Ferrán Garcés y rogándoles que dieran crédito a todo lo que les diría de su parte; además, el monarca les concedió ya su guiaje para acudir a Murcia y regresar, facilitándoles de esta forma el camino para que no encontrasen obstáculos en el caso de que, tal como deseaba, decidieran prestarle homenaje ${ }^{3}$. Dos o tres días duraron las conversaciones entre los dos comendadores y Ferrán Garcés, el cual logró que ambos accedieran a presentarse ante el monarca, iniciando el viaje inmediatamente; to demuestra el hecho de que el día 23 Jaime II volvió a conceder su guiaje a los comendadores, los cuales "venen a nos ab le amat cavaller nostre Ferran Garçés de Roda", garantizándoles también el regreso a sus respectivas encomiendas ${ }^{4}$. El rey les aseguraba, además, cumplir todo lo que Ferrán Garcés les había prometido de su parte, que no podía ser otra cosa que su intención de defenderles.

El día 25 de mayo los comendadores de Ricote y Cieza llegaron a Murcia, donde celebraron su encuentro con Jaime II, el cual les requirió que le obedecieran como a rey y señor. Sin embargo, aquellos le objetaron que no podían prestarle obediencia

2 Jaime ll ya se había servido en otras ocasiones de su consejero Ferrán Garcés de Rueda para obtener la adhesión de otros castillos y lugares. Véase $M^{a}$.T. FERRER I MALLOL, "Notes sobre la conquesta del regne de Múrcia per Jaume II (1296-1304)", en Homenatge a la memòria del Prof. Dr. Emilio Sáez, Barcelona, Universitat de Barcelona, Centre d'Estudis Medievals de Catalunya, Institució Milà i Fontanals. CSIC, 1989, pp. 30 y 34, y también La conquesta de les comarques meridionals valencianes per Jaume $/ 1$, en prensa, donde se hace alusión a estas negociaciones.

3 ACA, C, reg. 340 , fol. 79 r.

4 ACA, C, reg. 340 , fol. $86 \mathrm{~V}$. 
sin licencia expresa del maestre, pidiéndole 30 días para acudir a Castilla con el fin de obtenerla, a lo que el rey accedió, puesto que este era el plazo que iba dando a los habitantes del reino de Murcia para que le reconocieran como rey.

Mientras aquel 25 de mayo los comendadores de Ricote y Cieza iniciaron su viaje a Castilla para presentarse ante el maestre, Jaime II despachaba tres cartas relacionadas con estas negociaciones. Por la primera de ellas otorgaba su guiaje a los lugares de Ricote, Cieza, Ojós y Aledo, para que nadie los dañara durante aquel mes en que los comendadores de Ricote y Cieza, en representación de todos estos lugares, viajaban a Castilla ${ }^{5}$. La segunda carta iba dirigida al propio maestre Juan Osores, y cobra especial interés por constituir el primer contacto que Jaime II establecía con el máximo dirigente de la Orden de Santiago en relación con la ocupación del reino de Murcia. Por ella le hacía saber que Alfonso, al que siempre denomina rey de Castilla, le había hecho donación del reino de Murcia, tras lo cual él había tomado posesión «de la más noble partida d'aquel». Por esta razón, le rogaba que ordenase a los comendadores, que en aquel momento se dirigían a su presencia, y a todos los santiaguistas de Murcia que le obedecieran, a cambio de cuya lealtad él estaba dispuesto a «fazer ben e mercé a los comendadores e los freyres sobredichos, e mandener e deffender a dreyto a ellos e a todos lur bienes que vuestra Orden a en el dito regno de Murcia». El monarca le amenazaba, sin embargo, con actuar contra todos ellos, si no se sometían ${ }^{6}$. Por último, una tercera carta, unida a la anterior y con la misma petición de obediencia, envió Jaime II a Juan Iváñez, comendador mayor de Segura y de todo lo que la Orden de Santiago tenía en el reino de Murcia.

Los comendadores de Ricote y Cieza regresaron de Castilla a principios de junio, antes de que expirase el plazo de un mes que el monarca les había dado para que le prestasen obediencia. Las instrucciones que traían de parte del maestre eran bien claras: se someterian al monarca de Aragón si éste antes aprobaba y confirmaba todos los fueros, privilegios y libertades que los reyes de Castilla habían concedido a los santiaguistas del reino de Murcia hasta la fecha, y esto fue lo que suplicaron a Jaime II que llevara a cabo. El monarca accedió y el 10 de junio confirmaba todos sus privilegios, pero eso sí, con la condición de que le sirvieran e hicieran paz y guerra por él de los castillos y lugares que la Orden de Santiago tenía en dicho reino ${ }^{7}$. Satisfechos ambos comendadores con esta declaración, al día siguiente, II de junio de 1296, en la ciudad de Murcia y en la casa del monarca, juraron obediencia a Jaime II por sus respectivos lugares, así como también por Aledo, Negra, Ojós y demás territorios que tenían en el reino, prometiéndole, tal como les había pedido, hacer por él paz y guerra y todos los servicios que habían prestado a los anteriores soberanos de Murcia ${ }^{8}$.

De esta forma, pues, y después de tres semanas de negociaciones, las encomiendas de Aledo, Cieza y Ricote, comprendiendo esta última las villas de Abarán, Negra,

5 Jaime II también ordenó a sus oficiales y súbditos respetasen el guiaje concedido a los comendadores de Ricote y Cieza: ACA, C, reg. 340, fols. 93r y 97r. (1296, mayo, 25).

6 ACA, C, reg. 340, fol. 92v.

7 ACA, C, reg. 340 , fol. $127 \mathrm{~V}$.

8 Apéndice, doc. 1. 
Ojós y Puerto de la Losilla, se sometieron a Jaime II. Por lo que respecta al resto de las encomiendas santiaguistas del reino de Murcia, el monarca, en espera de su respuesta favorable tras la petición de obediencia que había hecho al comendador mayor de Segura, extensiva a todos ellos, quiso atraerse su fidelidad. Para ello, al día siguiente de recibir el juramento de los comendadores de Ricote y Cieza, otorgó su guiaje a todos los freires de la Orden de Santiago en el reino de Murcia, a sus bienes y a los habitantes de sus lugares, tanto cristianos como sarracenos; de igual forma, el día 14 también concedió guiaje y seguridad a Pedro Fernández, comendador de Moratalla, y a los lugares de Moratalla, Priego y Benizar, con la condición de que no dañasen los lugares del señorío real ${ }^{10}$.

El sometimiento de los santiaguistas de Murcia a Jaime II llevaba emparejado una serie de promesas de fidelidad, defensa y servicio por ambas partes que, como iremos comentando, no siempre se cumplirían. De momento, y por lo que respecta al monarca de Aragón, muy pronto y en diversas ocasiones iba a demostrar que la promesa que acababa de hacer de defender a los santiaguistas era auténtica, pues así le convenía para mantener la adhesión que acababan de otorgarle. Por ejemplo, enterado de que Jaime Pérez, su hermano natural y a quien el 23 de mayo había nombrado procurador del reino de Murcia ${ }^{11}$, se negaba a restituir a Juan Muntaner, comendador de los bienes que la Orden tenía en Orihuela, cierta cantidad de trigo que había tomado del lugar de Algorfa, le ordenó la restitución. El monarca recordó al procurador la protección que acababa de conceder a los santiaguistas de Murcia, por lo que le mandó que no les ocasionara daño alguno ${ }^{12}$. También quiso Jaime II proteger a los freires y lugares de la Orden que ya se habían sometido a su causa, contra posibles ataques de la población sarracena, y así hizo saber a los moros de Vélez Blanco, Vélez Rubio y Negra que el comendador de Ricote le había reconocido por rey y señor del reino de Murcia, por lo que les ordenaba que no le agraviaran, ni a él ni a sus lugares, mandando, además, a los de Negra que entregasen a dicho comendador los derechos que acostumbraban a darle ${ }^{13}$. Otra actitud a favor de los santiaguistas por parte del

9 ACA, C, reg. 340, fol. 128r. (1296, junio, 12). Sobre la presencia de pobladores musulmanes en las encomiendas santiaguistas de Murcia, véase el trabajo de M. RODRíGUEZ LLOPIS, «Repoblación y organización social del espacio en los señoríos santiaguistas del reino de Murcia (1235-1350)", Murguetana, 70 (1986), pp. 5-34.

10 ACA, C, reg. 340 , fol. $134 \mathrm{v}$.

11 Publicado por J.M. del ESTAL, Conquista y anexión de las tierras de Alicante, Elche, Orihuela y Guardamar del reino de Valencia por Jaime /l de Aragón (1296-1308), Alicante, Publ. de la Obra Social y Cultural de la Caja de Ahorros Provincial de Alicante, 1982, doc. 19 y Corpus documental, 1/ 1, doc. 91; también Mํ. T. FERRER I MALLOL, Organització i defensa d'un territori fronterer. La governació d'Oriola en el segle XIV, CSIC, Institució Milà i Fontanals, 1990, doc. 4.

12 ACA, C, reg. 340, fol. 144v. (1296, junio, 15).

13 ACA, C, reg. 340, fol. 177r.-v. (1296, junio, 26). Muy pronto los moros de Vélez Blanco y Vélez Rubio tendrían ocasión de acatar la orden del rey de defender a los santiaguistas, puesto que a mediados de julio y a raíz del ataque perpetrado por moros del reino de Granada a hombres que el comendador de Ricote había enviado de Murcia a Aledo, recibieron instrucciones de Jaime II de capturar a estos moros y obligarles a devolver lo tomado. Las mismas instrucciones dio el rey al alcaide de 
monarca de Aragón fue la de respetar concesiones por ellos otorgadas. Así nos consta que accedió a la súplica que le hizo Pedro Ruiz de San Cebrián, alcaide del castillo de Orihuela, de que se le respetasen los derechos sobre los tercios de las iglesias de Santiago de Murcia y Orihuela, que el maestre de Santiago le había otorgado ${ }^{14}$.

Por último, también tenemos constancia de que, en el mes de julio, los comendadores de Ricote y Cieza acudieron a presencia del rey para quejarse de que, con motivo de la concesión efectuada por el monarca a un vecino de Murcia, llamado Pedro Andrés, éste había recibido unos bienes en la ciudad que eran propiedad de la Orden de Santiago, queja que Jaime II también atendión ${ }^{15}$.

A finales del año 1296 Jaime II podía estar satisfecho. En el terreno militar dominaba casi todo el reino de Murcia, con excepción de Lorca, Alhama y otras pequeñas plazas. En cuanto a la actitud de los santiaguistas, el balance también era positivo: el maestre Juan Osores había adoptado una postura de aparente neutralidad y varias encomiendas del reino le habían reconocido ya como rey. $Y$ así, con este éxito inicial regresó a Valencia, dejando como procurador suyo, como hemos dicho, a Jaime Pérez.

\section{1297. FERNANDO PÉREZ, COMENDADOR DE RICOTE, OBJETO DE POLÉ- MICA}

De esta forma dio comienzo el año 1297, el segundo de la ocupación, con cierta tranquilidad en el terreno militar, que Jaime II aprovechó para dedicarse a asuntos de gobierno.

Pero en relación con los santiaguistas del reino de Murcia, ocurrió a primeros de junio un hecho, desconocido hasta ahora, que mantuvo ocupada la atención y preocupación del monarca aragonés durante un tiempo, y fue la decisión que tomó el maestre Juan Osores de sacar al comendador Fernando Pérez de la encomienda de Ricote para concederla a otro. Fue el propio maestre quien convocó al comendador a Capítulo para comunicarle su destitución, por unas causas que no hemos podido saber. Lo que sí, en cambio, conocemos es cual fue la inmediata reacción de Jaime II, el cual no podía consentir que un comendador, que un año antes le había jurado obediencia y le

Mula Pedro Zapata, a quien además requirió que «no lexedes fasser mal ne danno a los logares de la Orden ne a los habitantes en aquellos, que por nos segurados son m: ACA, C, reg. 340, fol. 237v. (1296, julio, 16).

14 ACA, C, reg. 340 , fol. 189v. (1296, junio, 29).

15 El 7 de julio el rey ordenó a Jaime Pérez, procurador del reino de Murcia, hiciera restituir estos bienes a la Orden de Santiago, misión que el 1 de junio del siguiente año, por estar el procurador ocupado en muchos asuntos, encomendó al jurisperito de Murcia Nom de Deu. Ambas cartas en ACA, C, reg. 108, fol. 82r.-v. La concesión efectuada a Pere Andrés, a la que aluden estas cartas y que motivó la queja de los comendadores de Ricote y Cieza, había tenido lugar el 10 de mayo de aquel año, cuando Jaime II, encontrándose en el asedio de Orihuela, le concedió las casas y posesiones que, habiendo pertenecido a un tal Albalat, tenian en aquel momento Guillermo Pérez de Foces y García Gil de Sagra, a quienes el monarca se las confiscó en castigo a su rebeldía: ACA, C, reg. 194, fol. 147v. 
estaba siendo fiel, fuese substituido por otro que tal vez resultase contrario a su causa, y más tratándose de una encomienda de la importancia de la de Ricote. Por ello, al enterarse, rogó inmediatamente al maestre que en consideración suya siguiese manteniendo a Fernando Pérez al frente de la encomienda de Ricote, puesto que era un hombre bueno, en el que se podía confiar y, además, había dirigido la encomienda con lealtad, "assí que danno ni menoscabo no a venido por él al regno nuestro de Murcia». Por esta razón, Jaime Il pidió al maestre que, aún en el caso de que el comportamiento de Fernando Pérez hacia la Orden hubiese sido tal que mereciera su destitución, consintiera al menos en mantenerlo en Ricote hasta que le certificase a quien quería poner al frente de esta encomienda, en cuyo caso, le decía textualmente: "que se haga a nuestra voluntad» ${ }^{16}$.

Firme, pues, en su defensa del comendador, Jaime II ordenó también al procurador del reino de Murcia Juan Pérez, intercediera de su parte ante el maestre a favor de la restitución de la encomienda de Ricote a Fernando Pérez y no consintiera que aquel hiciera cambio alguno sin su licencia y mandato ${ }^{17}$.

Dos meses duró la espera sobre la decisión del maestre, hasta que a finales de agosto éste comunicó a Jaime II que, atendiendo su petición, consentía en mantener a Fernando Pérez al frente de la encomienda de Ricote. El rey agradeció a Juan Osores su cambio de postura y le rogó diera también al comendador las retenencias de los castillos, tal como se acostumbraba, es decir, la provisión de alimentos, guarnición y otras cosas necesarias para su conservación y defensa ${ }^{18}$. Rápidamente el monarca comunicó a Fernando Pérez la decisión del maestre y le pidió su ayuda en la empresa que estaba llevando a cabo en el reino de Murcia $^{19}$, al mismo tiempo que por otra carta le anunciaba, a él y al nuevo comendador de Segura, Lope Fernández, dieran crédito a lo que de su parte les diría su enviado Ferrán Garcés de Rueda ${ }^{20}$. Pero ¿qué misión llevaba a este consejero de Jaime II ante los dos comendadores?

No creemos equivocarnos al pensar que Ferrán Garcés de Rueda, que el año anterior, tal como hemos señalado, había negociado la sumisión de Ricote, Cieza y Aledo, fue enviado en aquellos momentos ante los dos comendadores con la misma misión: obtener, por una parte, de Fernando Pérez la renovación de su lealtad a la causa aragonesa después de haber sido repuesto en la encomienda y, por otra, requerir al comendador de Segura el juramento de obediencia a Jaime II. Así parece

16 Apéndice, doc. 2. Jaime II escribió esta carta durante la breve escapada que realizó a Lorca, con el fin de asediaria.

17 ACA, C, reg. 253, fol. 42v. (1297, junio, 29).

18 Jaime II, agradeciendo al maestre su decisión de mantener a Fernando Pérez en la encomienda de Ricote, le aseguró que «en los feytos vuestros e de la vuestra Orden faremos toda vía de guissa que vos en seredes pagado»: ACA, C, reg. 109, fol. 278r. (1297, agosto, 27). Sobre la retenencia de los castillos en el $s$. XIV véase, Mª.T. FERRER I MALLOL, “La tinença a costum d'Espanya en els castells de la frontera meridional valenciana (segle XIV)», Miscel.lània de Textos Medievals, 4 (1988), pp. $\uparrow-102$.

19 ACA, C, reg. 109, fol. 278r.-v. Publicado por R. SAINZ DE LA MAZA, La Orden de Santiago, doc. 123 y J. M. del Estal, Corpus documental, 1/2, doc. 88.

20 ACA, C, reg. 109, fol. 278v. (1297, agosto, 27). 
indicarlo el hecho de que el día 5 de octubre el monarca, como solía hacer a favor de las villas que le prestaban lealtad, recibió bajo su guiaje y protección especial el lugar de Segura de la Sierra ${ }^{21}$.

\section{LA RETENENCIA DE LOS CASTILLOS SANTIAGUISTAS. INDIFERENCIA DEL MAESTRE}

Superado, pues, el problema que para Jaime II supuso la posible substitución en la encomienda de Ricote de Fernando Pérez, se produjo a comienzos de 1298 la vuelta de Jaime II al reino de Murcia para emprender el asedio de Alhama. Allí se encontraba ya el 4 de enero, día en que, enterado de que el comendador santiaguista de Aledo Pay Ferrándiz quería entrevistarse con él, ordenó a sus oficiales no le hicieran ningún embargo, ni a él ni a sus cabalgaduras ${ }^{22}$.

Desconocemos el motivo de la visita del comendador de Aledo al monarca, pero sí nos consta documentalmente que tanto este comendador, como el repuesto comendador de Ricote Fernando Pérez y también Juan Martínez, comendador de Cieza, seguían manteniendo un comportamiento leal a la causa de Aragón. Así lo reconoció el propio Jaime II, quien, en consideración a la buena disposición de los tres comendadores y para que mejor pudiesen custodiar sus castillos, les prometió 10.000 maravedís procedentes de las rentas de la Orden de Santiago en Murcia, mientras durase la guerra con Castilla, con la posibilidad de darles mayor cantidad si la necesitaban. Además, les aseguró que ni él, ni el procurador en el reino de Murcia, les quitarían sus castillos y lugares y, si alguno lo hacía, él se los devolvería; y por último, y esto es importante, les prevenía de una posible reacción del maestre contraria a ellos, prometiéndoles que, en caso de que esto sucediera, él los defendería enérgicamente: «si forsan magister dicti Ordinis vellet procedere seu procederet ratione premissa contra vos seu aliquem vestrum, nos iurabimus et deffendemus vos totis viribus" ${ }^{23}$.

El contenido de esta carta que el rey envió a los comendadores refleja, por un lado, la situación comprometida de éstos, siempre temerosos de que sus servicios a Jaime II ocasionasen el enojo del maestre, y por otro, la desconfianza que éste inspiraba al rey aragonés, fundamentada, además, en aquella ocasión por el hecho de que

21 ACA, C, reg. 106, fol. 14v. Entre la llegada de Ferrán Garcés ante el comendador de Segura y la concesión del guiaje a este lugar, transcurrieron los 30 días que Jaime Il solía dar a las poblaciones para que decidieran aceptarle como rey de Murcia y prestarle obediencia, lo que seguramente hizo el comendador de Segura durante los primeros días de octubre de 1297.

22 ACA, C, reg. 256, fol. 7r. También nos consta que por las mismas fechas el comendador de Moratalla Juan Álvarez, que se encontraba en Castilla por voluntad de Jaime II, deseaba entrar en Aragón para verse con el comendador de Montalbán García López. El monarca aragonés ordenó a sus oficiales no se lo impidiesen, siempre que no tratase asuntos perjudiciales para el reino: ACA, C, reg, 107 , fol. $187 \mathrm{v}$. (1298, enero, 9).

23 ACA, C, reg. 196, fol. 129r.-v. (1298, febrero, 7). También en AHN, Aledo, cajón 50, núm. 10. En un traslado de 1757. Publicado por J. TORRES FONTES, Colección de documentos para la historia del reino de Murcia. II, Documentos del siglo XIII, (Codom), II, Murcia, Academia de Alfonso X el Sabio, 1969, doc. CXXVIII y J.M. del ESTAL, Corpus documental, 1/1, doc. 159. 
todavía no había atendido la petición que le había hecho en agosto del año anterior de proveer a la retenencia de los castillos santiaguistas de Murcia. Por ello, al día siguiente de hacer todas estas promesas a los comendadores, Jaime II escribió al propio maestre Juan Osores en unos términos bastante duros, que en el fondo eran una auténtica amenaza y una invitación a que abandonase su actitud, tan poco definida. En primer lugar, le exigía una orden a los santiaguistas del reino de Murcia de obediencia a su causa, y después, tras recordarle nuevamente que los castillos de Ricote, Cieza y Aledo, a causa de la guerra con Castilla, precisaban mayor retenencia, le pedía los 10.000 maravedís que le había solicitado, a saber, 6.000 para el de Aledo y 4.000 para el de Cieza, puesto que sólo así, él le garantizaba que estos lugares continuarían bajo la propiedad de la Orden de Santiago; y porque el cumplimiento de estas peticiones no admitía tardanza, le dio 30 días de plazo para que respondiera ${ }^{24}$.

Pero el maestre, obligado a mantener su fidelidad al rey Fernando IV de Castilla, siguió sin enviar el dinero necesario para los mencionados castillos de Murcia, las rentas de los cuales resultaban en aquel momento insuficientes para su defensa. Fue entonces cuando Jaime II, cumplido el plazo que había dado al maestre y buscando una solución intermedia para no tener que cumplir su amenaza de dejar a la Orden sin la posesión de los tres castillos, lo que no hubiera hecho más que empeorar las difíciles relaciones que mantenía con el maestre, gestó la idea ya conocida: que fuese el comendador mayor de Montalbán en Aragón el que se encargase de su custodia. De esta forma se garantizaría la fidelidad de las tres encomiendas de la zona ocupada de Murcia al sacarles de la inmediata sujeción al maestre, consejero, como hemos dicho, del rey de Castilla, circunstancia que siempre suponía una amenaza. Propuesta la idea al propio comendador de Montalbán, a la sazón García López, y habiendo contestado que no efectuaría la guarda de los castillos de Murcia sin orden expresa del maestre, Jaime II escribió nuevamente a éste el 15 de marzo de aquel año de 1298 ofreciéndole una alternativa de actuación: o bien «dedes conseyllo a los ditos castiellos», o bien «mandedes al comendador de Montalbán sobredito que él y dé conseyllo et ayuda, en manera que por deffayllimiento de guarda et de retenimiento los ditos castiellos non se ayan de perder a vos et a la Orden ${ }^{25}$.

Ante la alternativa ofrecida por Jaime II, el maestre prefirió la que dejaba en manos del comendador de Montalbán la ayuda económica a las tres encomiendas de Murcia. Esto es lo que se deduce de la carta que Jaime ll envió a éste el 19 de marzo, pidiéndole que pagase 10.000 sueldos jaqueses a su escribano Bertrán Desvall para la guarda de los castillos de Ricote, Aledo y otros del reino de Murcia, los cuales no podían ya defenderse sin su ayuda ${ }^{26}$; parte de esta cantidad decidió el rey asumirla: él pagaría 4.000 y el comendador 6.000 , como así se lo hizo saber a Jaime Pérez, su

24 ACA, C, reg. 107, fols. 225v.-226r. (1298, febrero, 8). Publicado por R. SAINZ DE LA MAZA, La Orden de Santiago, doc. 125 y J.M. del ESTAL, Corpus documental, 1/2, doc. 106.

25 ACA, C, reg. 110, fol. 33v. (1298, marzo, 15). Publicado por R. SAINZ DE LA MAZA, La Orden de Santiago, doc. 126 y J.M. del ESTAL, Corpus documental, 1/2, doc. 107.

26 ACA, C, reg. 110, fol. 34r. y reg. 264, fol. 252r. Publicado por R. SAINZ DE LA MAZA, La Orden de Santiago, doc. 127 y J.M. del ESTAL, Corpus documental, 1/2, doc. 108. 
procurador en Murcia, a quien anunció que en breve recibiría esta cantidad con destino a la retenencia de los mencionados castillos ${ }^{27}$. Además, para que el comendador de Montalbán no tuviera dificultades en reunir este dinero, mandó a sus oficiales que cuidaran de que los vasallos del comendador pagasen a éste la suma de dinero que les exigiera ${ }^{28}$.

Todas estas instrucciones, encaminadas a la defensa y conservación de las encomiendas santiaguistas de Murcia, fueron completadas con otra orden que dio Jaime II al procurador de este reino y a sus oficiales de mantener y defender a los freires de la Orden de Santiago y sus bienes ${ }^{29}$, sin olvidar tampoco el monarca las encomiendas alejadas de la zona militarmente ocupada, ya que también mandó proteger al comendador de Moratalla Juan Álvarez, siempre y cuando éste correspondiera con su leal$\operatorname{tad}^{30}$.

\section{DETERIORO DE LAS RELACIONES CON LOS SANTIAGUISTAS}

De lo dicho hasta ahora se desprende que las relaciones de Jaime II con los santiaguistas de Murcia, y en especial con el maestre, eran muy delicadas y, pese a la buena disposición que hasta aquel momento parecían haber adoptado los comendadores de Ricote, Cieza y Aledo, su comprometida situación, entre la fidelidad que debían al maestre, consejero del rey Fernando IV de Castilla, y la lealtad que habían jurado al monarca de Aragón, hacía que éste no pudiera estar, ni tranquilo ni confiado respecto a ellos, como las circunstancias se lo irian demostrando.

En efecto, nos consta como ya en el mes de febrero de aquel año de 1298 los de Cieza atentaron contra la paz establecida entre Jaime Il y el reino de Granada, al robar y matar a unos jinetes de Granada que, de regreso de Castilla con todo lo que de alli habian extraído, se refugiaron en Cieza confiando en la amistad reinante, suceso que provocó la rápida actuación del monarca aragonés ${ }^{31}$.

Este comportamiento de los de Cieza se sumó a otros sucesos que empezaron a producirse en el reino y que evidenciaban la hostilidad de que empezaban a dar muestra

27 ACA, C, reg. 264, fol. 247r. (1298, marzo, 19).

28 ACA, C, reg. 110, fol. 33v. Publicado por R. SAINZ DE LA MAZA, La Orden de Santiago, doc. 128 y J.M. del ESTAL, Corpus documental, 1/2, doc. 109.

29 ACA, C, reg. 107, fol. 290v. (1298, marzo, 10). Cit. M. RODRÍGUEZ LLOPIS, La expansión territorial castellana, p. 121.

30 ACA, C, reg. 107, fol. 246v. (1298, febrero, 9).

31 Jaime 11 ordenó al procurador del reino de Murcia Jaime Pérez certificase el suceso y obligase a los de Cieza a efectuar enmienda del robo, orden, que al no ser cumplida, tuvo que renovar cuatro meses más tarde al sucesor en la procuración del reino de Murcia Jaume de Xérica: ACA, C, reg. 107, fol. 219 r (1298, febrero, 11) y r. 112, fol. 64r (1298, junio, 22).

32 Jaime II, desde Nápoles, comunicó al procurador Jaume de Xèrica que le complacían mucho las noticias que le había dado sobre la tranquilidad y estado pacífico en que se encontraban los reinos de Valencia y Murcia: ACA, C, reg. 113, fols. 164v.-165r. (1299, junio, 10). Jaume de Xèrica fue nombrado procurador de los reinos de Valencia y Murcia el 9 de abril de 1298: ACA, C, reg. 196, fol. 183r. Publicado por Ma.T. FERRER I MALLOL, Organització i defensa, doc. 14. 
los pobladores de origen castellano de los lugares ganados para Jaime II, los cuales, alentados por una cierta recuperación en Castilla, negociaban secretamente con este reino. Así, a pesar de que durante los próximos meses la calma en el terreno militar fue una realidad ${ }^{32}$, los movimientos de conspiración en la frontera, protagonizados tanto por castellanos que entraban en Murcia, como por murcianos que entraban en Castilla, empezaron a ser noticia. No faltaron santiaguistas en estas conspiraciones, pues por el mes de octubre de 1299 el monarca se enteró de que algunos freires castellanos de esta Orden pretendían acudir a las tierras del reino, y para evitar los problemas que su presencia podría provocar, ordenó a Lope Ferrench de Luna, procurador de Aragón, y a Jaume de Xèrica, procurador de los reinos de Valencia y Murcia, no se lo permitieran hasta que certificaran este hecho o recibieran otro mandato suyo ${ }^{33}$.

Con la llegada del año 1300 la fuerza del monarca aragonés empezó a debilitarse, haciéndose evidente por un lado la huida mudéjar y por otro la despoblación del reino, cuya procuración fue encomendada a Bernat de Sarrià el 1 de abril de aquel año, en substitución de Jaume de Jèrica ${ }^{34}$. Por lo que se refiere a las relaciones con los santiaguistas, éstas empezaron a hacerse cada vez más difíciles por los continuos agravios que seguían infiriendo a gentes del rey de Granada, pese a la tregua existente entre los dos reinos ${ }^{35}$. Nos consta al respecto que durante aquel año gentes de Aledo degollaron a dos moros de Vélez Blanco ${ }^{36}$, y que también el comendador y hombres de Moratalla capturaron a 14 moros de Granada, nueve de los cuales enviaron a Mallorca, reteniendo a los restantes en Moratalla ${ }^{37}$. Por otra parte, tenemos noticia de que en noviembre las gentes de Aledo, Ricote y Cieza todavía debían al monarca el monedaje, por lo que Jaime II tuvo que ordenar a los comendadores de dichos lugares obligaran a sus gentes a efectuar el pago ${ }^{38}$.

Pero fue sobre todo a partir de mediados de aquel año, a raíz de la convocatoria de tropas que llevó a cabo Bernat de Sarrià, en nombre del monarca aragonés, para el sometimiento de las plazas que le faltaban, cuando los santiaguistas empezaron a inclinarse al lado castellano. Probablemente su cambio de actitud se debió a las noticias que circulaban de una próxima llegada de Fernando IV de Castilla al reino de

33 ACA, C, reg. 114, fol. 51v. (1299, noviembre, 2).

34 Ma.T. FERRER I MALLOL, Organització i defensa, doc. 16.

35 Al enterarse Jaime II de que desde los lugares de las Órdenes en el reino de Murcia se estaba agraviando a los de Granada, con los cuales quería seguir manteniendo la tregua existente, ordenó a su procurador Bernat de Sarrià hiciese enmendar los daños y, en caso de que los de las Órdenes hubiesen asimismo sufrido represalias, pidiera al nuncio del rey de Granada la reparación de los males: ACA, C, reg. 118, fol. 142r. (1300, septiembre, 15). Cit. Mª. T. FERRER I MALLOL, Organització i defensa, p. 43.

36 ACA, c.r Jaime II, caja 122, núm. 1423 (s.f. [1300]).

37 Como Jaime Il y el rey de Granada habían acordado liberar a todos los presos que, desde que firmaron la paz entre ellos, las gentes de ambos reinos habian capturado, Jaime ll en aquel momento ordenó al procurador Bernat de Sarrià que liberase a los moros retenidos por el comendador de Moratalla y por los de Aledo: ACA, C, reg. 117, fol. 172r.-v (1300, junio, 4).

38 ACA, C, reg. 332, fol. 121r. (1300, noviembre, 8). Publicado por J.M. del ESTAL, Corpus documental, 1/2, doc. 117 . 
Murcia, pues hay un hecho fácilmente constatable, y es que los momentos de deterioro de las relaciones entre Jaime II y los santiaguistas durante los ocho años de ocupación aragonesa, coinciden con los anuncios de una recuperación castellana o de la venida de Fernando IV. Fuese ésta u otra la razón, lo cierto es que hacia finales de noviembre de aquel año, el maestre, haciéndose seguramente eco del sentir de muchos de sus vasallos, se quejó a Jaime II de que Bernat de Sarrià hubiese requerido la participación de los lugares santiaguistas de Murcia en la guerra contra Castilla. La respuesta del monarca aragonés a Juan Osores fue inmediata y contundente, recordándole que cuando los reyes de Murcia, sus antecesores, dieron estos lugares a la Orden de Santiago, exigieron de ellos fidelidad en la paz y en la guerra, por lo que él, que era rey y señor de este reino, debía ser correspondido por ellos con la misma lealtad; además, le decía que, aún cuando sostenía guerra con Castilla, él no obligaba a los freires y religiosos de Santiago que estaban en Murcia a ir a las huestes y cabalgadas, sino únicamente convocaba a los legos y a los habitantes de los lugares de su Orden, declaración que el mismo día el monarca también transmitió al comendador de Ricote ${ }^{39}$.

Estas quejas de los santiaguistas reflejaban un hecho evidente, como era su resistencia en aquel momento, a prestar ayuda a Jaime II contra los castellanos, que eran a quienes en realidad estaban sirviendo. Esto es lo que el 19 de aquel mismo mes de diciembre, es decir, al día siguiente de la capitulación de Lorca, el monarca aragonés denunció al propio maestre, a quien comunicó que los comendadores y gentes de Ricote, Peña de Ojós, Aledo y Cieza estaban favoreciendo a Castilla al inferir muchos daños a los lugares de Murcia, destacando la traición del comendador de Ricote, Fernando Pérez, el cual, según palabras del monarca, «acuylle e recibe nuestros enemigos en los ditos castiellos de la Orden» y además, y esta es una noticia interesante, «fizo nos perder el castiello de Mula» ${ }^{40}$. Así pues, resulta evidente por esta declaración de Jaime Il que a la revuelta y pérdida de esta población, acaecida durante los primeros meses de aquel año, había tenido mucho que ver la actitud desleal y traidora de los santiaguistas, en especial del que presidía una de sus encomiendas más importantes. La conducta de Fernando Pérez en aquellos momentos era bien diferente a la que, según hemos comentado, había mostrado al iniciarse la ocupación aragonesa del reino y que evidencia, como muy bien dice $\mathrm{M}^{\mathrm{a}}$ Teresa Ferrer, que el juramento y homenaje prestados por muchos súbditos del reino de Murcia a Jaime II no fue sinónimo de lealtad, sino de puro oportunismo ${ }^{41}$.

En la carta de denuncia de estos hechos, y en otras que aquel mismo día Jaime II hacía llegar al maestre, pedía a éste que, a causa del mal comportamiento de los

39 Apéndice, doc. 3.

40 ACA, C, reg. 293, fol. 3v. (1300, diciembre, 18). Publicado por J.M. del ESTAL, Corpus documental, 1/2, doc. 134 y "Nuevos datos sobre la capitulación y conquista aragonesa de Lorca», en Homenaje al Profesor Juan Torres Fontes, I, Murcia, Universidad de Murcia,' Academia Alfonso X el Sabio, 1987, pp. 431-464, doc. 4.

$41 \mathrm{M}^{a}$.T. FERRER I MALLOL, La conquesta de les comarques meridionals valencianes per Jaume II, en prensa. 
comendadores citados y para que no le ocasionaran más daños, le hiciese entrega de los castillos de Ricote, Aledo, Cieza y Ojós mientras durase la guerra con Castilla, prometiéndole su devolución en cuanto ésta terminase, y que instalase en ellos por comendador a "algun buen freyre» que se encargase únicamente de administrar sus rentas y al cual hiciese comendador de Montalbán en Aragón, puesto que así «más volenteroso será a guardar el pro de la Orden teniendo la Comendaria de Montalbán». En segundo lugar le rogaba que no sólo expulsara a Fernando Pérez de la encomienda de Ricote, sino que incluso lo hiciera salir del reino de Murcia como castigo por su traición. Y por último le proponía que fuese precisamente Juan López, comendador de Socovos y portador de las cartas, el elegido para dirigir las encomiendas de Murcia juntamente con la de Montalbán, por ser un hombre leal, que había mejorado su encomienda y había hecho mucho bien a la Orden ${ }^{42}$. Precisamente éste tenía que decir al maestre, de parte de Jaime II, que si en el plazo de 30 días no había cumplido sus peticiones, él actuaría contra los castillos y lugares santiaguistas mencionados.

¿Cuál fue la respuesta del maestre a estas propuestas de Jaime II? Los testimonios documentales dejan claro que únicamente a la expulsión de Fernando Pérez de la encomienda de Ricote no puso objeciones, pero no aceptó el resto de las peticiones del monarca de Aragón. En efecto, no tenemos constancia de que Juan Osores se aviniera a perder el gobierno de los castillos de Murcia, dejando al frente de los mismos a meros administradores, puesto que, aparte de la substitución en Ricote, no se produjo en Cieza y Aledo relevo de sus comendadores. Tampoco el comendador de Socovos fue nombrado comendador conjunto de las encomiendas de Murcia y de la Encomienda mayor de Montalbán, sino que a mediados del siguiente año el maestre colocó al frente de esta última a Fortún de Vergua ${ }^{43}$.

En cuanto a la actitud de Fernando Pérez tras la traición que había protagonizado, no se mostró contrario a abandonar la encomienda de Ricote si el rey así lo quería, pero le pidió entrevistarse con él, así como un plazo para poder entregar al maestre los castillos. En la respuesta que Jaime II le dio, le confesó que había sido el procurador del reino de Murcia y otras personas quienes le habían acusado de que no había sido «tan bien levado en los nuestros servicios como avríades podido fer», puesto que cuando requerían su ayuda, siempre encontraba alguna excusa, dando por el contrario favor a sus enemigos. El rey le recordó asimismo, en tono de reproche, el juramento que en su día le había prestado de tenerle por rey de Murcia y que no hubiera debido olvidar, mostrando, eso sí, su complacencia en celebrar la entrevista que le solicitaba, donde tratarían del plazo para que devolviera los castillos y lo que pensaba hacer al respecto ${ }^{44}$. Fernando Pérez abandonó muy pronto la encomienda, siendo

42 ACA, C, reg. 293, fols. 4r.-5r. (1300, diciembre, 19). Cartas publicadas por J.M. del ESTAL, Corpus documental $1 / 2$, docs. 133,135 y 136 y Nuevos datos, docs. 3,5 y 6 .

43 Ver R. SAINZ DE LA MAZA, La Orden de Santiago, pp. 96-98.

44 ACA, C, reg. 293, fol. 29r. (1300, diciembre, 28). Publicado por J.M. del ESTAL, Nuevos datos, doc. 14 y Corpus documental, 1/2, doc. 144. 
sustituido por el hasta entonces comendador de Moratalla Juan Álvarez, qué, además, era aragonés ${ }^{45}$.

\section{1301. ACTIVIDAD MILITAR Y ATAQUE DEL MAESTRE A CIEZA}

En este estado de cosas y tras la rendición de Lorca acaecida el 21 de diciembre, el año 1301 dio comienzo, por una parte, con la orden de Jaime II de expulsión del reino de Murcia de castellanos y gallegos sospechosos ${ }^{46}$, y por otra, con el aviso de que tropas castellanas, dirigidas por el propio rey Fernando IV, iban a llegar al reino de Murcia en socorro de Lorca y Mula. Los llamamientos a combatir de Bernat de Sarrià, procurador del reino, fueron continuos. Uno de los convocados fue el comendador santiaguista de Cieza Juan Martínez y sus gentes, los cuales a principios de enero manifestaron al propio Jaime II su temor de recibir gran daño de los castellanos si acudían a la hueste, inquietud que refleja una vez más su comprometida situación y que el monarca trató de calmar ordenando al procurador que actuara de forma que los de Cieza no sufriesen daño ${ }^{47}$. En cuanto a la encomienda de Aledo sabemos que por aquel mes intervino en escaramuzas, pues si por una parte algunos de sus hombres se apoderaron en Totana de dos acémilas que hombres de Montblanc y Prades habían traído en servicio del monarca, capturando a los acemileros ${ }^{48}$, a fines de mes elevaron sus protestas al monarca por lo daños, pérdidas y menoscabos que habían sufrido por el rey de Granada y pidiéndole poder recuperar todo lo que les había sido tomado ${ }^{49}$. En realidad los agravios eran recíprocos, pues también el rey de Granada se había quejado de los males que los de la Orden inferían a los de su tierra, pidiendo por ello una satisfacción ${ }^{50}$.

El temido ataque del ejército castellano se hizo realidad durante la primera quincena de febrero, pero al haber llegado demasiado tarde para defender Lorca, se marchó tras abastecer Mula y Alcalá, todavía rebeldes a Aragón.

45 El 24 de diciembre Jaime II, quejoso de que Juan Álvarez, comendador de Moratalla, todavía no le había reconocido por rey de Murcia, le convocó a su presencia en un plazo de 20 días para que efectuara el homenaje: ACA, C, reg. 293, fol. 21v. Publicado por J.M. del ESTAL, Nuevos datos, doc. 11 y Corpus documental, 1/2, doc. 141. Sin embargo, ante los acontecimientos producidos por el comportamiento del comendador de Ricote, la entrevista debió traer consigo, no sólo el juramento de obediencia, sino además su traslado al frente de esta encomienda.

$46 \mathrm{M}^{\mathrm{a}}$.T. FERRER I MALLOL, Organització $i$ defensa, pp. 34 y ss.

47 ACA, C, reg. 118, fol. 3V. (1301, enero, 13).

48 ACA, C, reg. 118, fol. 1v. (1301, enero, 11).

49 ACA, c.r. Jaime II, caja, 6, núm. 819. (1301, enero, 27).

50 Es elocuente al respecto la contestación, que a fines de 1300 , dio Jaime II a las querellas presentadas por el rey de Granada por los daños que los santiaguistas le inferían: «entendiemos por el dito Bernat las querellas que vos avíades de los comendadores de los castiellos de las Ordenes. Ond vos fazemos saber que nos avemos feyto venir delant nos el comendador de Moratalla e los otros comandadores, e ellos tanbién an nos mostrado muy grandes querellas que han de los de vuestra tierra, assí que han assegurado muy bien e complidament en nuestro poder que farán luego render e satisfer todo aquello que sean tenidos a vos ni a las vuestras gentes del tiempo de la paz enca, e que vos también que fagades fazer a ellos otro tał»: ACA, C, reg. 334, fol. 6r. (1300, diciembre, 25). 
Una vez pasado el peligro que supuso la pasajera presencia castellana, el afán del procurador Bernat de Sarrià se centró en hacer volver a los santiaguistas rebeldes de Murcia al servicio de Jaime II. Concretamente a primeros de marzo, y tras hablar con los de Cieza, Ojós y con los moros de Ricote, consiguió de todos ellos su promesa de servir al rey de Aragón contra Castilla y de que todo castellano que acudiese a aquellos lugares sería "pres e retengut», a cambio cuya fidelidad el procurador les aseguró que los defendería; los moros de Ricote prometieron, además, la entrega de 40 rehenes ${ }^{51}$.

Los servicios que Bernat de Sarrià estaba prestando a Jaime Il le hicieron merecedor de una recompensa: la concesión que el monarca le hizo de la villa santiaguista de Negra. Fue seguramente este hecho, que suponía el desmembramiento del patrimonio santiaguista de Murcia, unido a la noticia que tuvo el maestre Juan Osores a finales de marzo de que dicho procurador había asediado Ricote y los demás lugares de la Orden, lo que hizo decidir al maestre a ir al reino de Murcia para defenderlos ${ }^{52}$. A mediados de abril se encontraba ya en el reino con unas huestes compuestas por 500 caballeros y 2.000 peones, tal como lo comunicaron al rey el concejo de Murcia y Jaime de Besora, lugarteniente del procurador, el cual convocó a todos los vecinos del reino para que estuviesen preparados para rechazar al enemigo y ordenó a los 30 ballesteros enviados por el concejo de Murcia se situasen en Cieza, lugar por donde se temía la invasión ${ }^{53}$. Bernat de Sarriá, por su parte, envió a defender Cieza a Ato de Lesu, el cual se presentó con 20 caballeros, siete suyos y trece de los de Lorca, y 20 peones ${ }^{54}$.

El temor de los de Murcia no era infundado, ya que el día 22 de abril el maestre Juan Osores, con 500 hombres a caballo, 4.000 peones, (más de los que se esperaba), y un número indeterminado de ballesteros, entraron en Cieza por la noche, matando a muchos vecinos y haciendo prisioneros, entre otros, a don Ato de Lesu y a su compañía. El ataque fue comunicado a Jaime Il al día siguiente por el concejo de la ciudad de Murcia, el cual avisó al monarca que había muchos más castellanos que se disponían a entrar en el reino ${ }^{55}$.

51 ACA, c.r. Jaime II, caja 89, núm. 10.898. ([1301], marzo, 7 y caja 8, núm. 1110 (1301, marzo, 7). Este último documento está publicado por P. GUICHARD, Un señor musulmán en la España cristiana: el «rais» de Crevillente (1243-1318), Alicante, 1976, doc. 4.

52 El 24 de marzo Bernat de Sarrià comunicó a Jaime Il que el maestre de Santiago «era vengut ab gran cavalleria entro a Feylí (Hellín), e fo ver que.y vené, per ço car avia entés que yo era vengut a Ricot e als altres locs dels Ordens e avia entés que.Is teníem asseegats»: ACA, c.r. Jaime II, caja 91, núm. 11.058.

53 ACA, c.r. Jaime II, caja 10, núms 1342 y 1343 (1301, abril, 19).

54 ACA; c.r. Jaime II, caja 112, núm. 325 (s.f.) [1301, abril].

55 «Sennor, a la vostra alta senyoria fem saber que yr dissabte, que fo XXII dies anats del mes de abril, vengueren e plegaren al cortijo de Çeçe el maestre d'Uclés ab çinçents hòmens a cavall e quatre mília peons e més, e ab ballesters de mont que avien, combateren molt regrament el dit cortijo. Et esta nit entraren e preseren aquell et ay y prés el noble don Ato de Lesu que y estave ab companya, et tots quants y eren an presos e cativats e molts morts. Et segons que.ns dien, deven venir e ésser molts grans gens que venen per entrar en esta terra e que volen talar los pans... "s: ACA, c.r. Jaime II, caja 10, núm. 1354. (1301, abril, 23). 
El ataque del maestre de Santiago a Cieza dejó sorprendido a Jaime II, quien sólo cuatro días después de producirse escribió a Juan Osores para requerirle que dejase "de fazer mal e dayno a nos o a nuestras gentes e a nuestros regnos», pues de lo contrario él respondería a su rebeldía actuando contra los lugares santiaguistas de Murcia ${ }^{56}$. Pero la carta tenía además otra finalidad: conocer cuáles eran las intenciones futuras del maestre y sobre todo la razón de su ataque, o en palabras del monarca «porqué vos sodes movido a fazer esto». El rey le anunciaba la visita del comendador de Museros García Lorenzo, así como la de Bernat de Sarrià, el cual tenía instrucciones de que si el maestre cumplía lo que en su día le había prometido, se pusieran de acuerdo y entonces no recibiría daño de su parte.

Un mes tardó Juan Osores en contestar al monarca aragonés a través de una carta que refleja el carácter fuerte y obstinado que le dominaba ${ }^{57}$. En ella le decía que no había entrado en Cieza para hacerle mal o «deservirle», sino que «Cieza punnámosla en cobrar, porque era nuestra" y no había ninguna razón que le impidiera conservar lo que le pertenecía. El maestre también se negaba a prestarle el homenaje que le pedía por los castillos, aunque, si le devolvía Negra «et todo lo al que nos fue tomado», le prometía que ni de él ni de sus castillos recibiría daño alguno. Finalmente, le pedía que mandase a sus oficiales que no planteasen pleito alguno hasta que él le enviara a su procurador, ya que sabía que algunos, aprovechando la situación de guerra, se atrevían a pedir propiedades de la Orden sin tener derecho alguno. Estas palabras del maestre indican claramente que el ataque de Juan Osores a Cieza fue una respuesta a la pérdida para la Orden de Santiago de Negra y de otras plazas, así como también una advertencia a Jaime II para que la política que estaba llevando en el reino no comportase la desmembración del patrimonio santiaguista de Murcia, como estaba sucediendo.

\section{TRATOS DE BERNAT DE SARRIÀ CON EL MAESTRE JUAN OSORES. RESTA- BLECIMIENTO DE BUENAS RELACIONES}

El ataque del maestre de Santiago a Cieza y su declaración a Jaime II de que no le haría homenaje por los castillos del reino de Murcia, ponía en serio peligro el apoyo de los santiaguistas de este reino a la causa de Aragón. Por ello el procurador Bernat de Sarrià se propuso inmediatamente continuar negociaciones con todos ellos, y sobre todo con el propio maestre, para renovar su adhesión. A este fin nos consta que, a mediados de mayo, consiguió ya que el comendador de Aledo y sus hombres le hicieran homenaje a él, en nombre de Jaime Il que en aquel momento se hallaba en Lérida, prometiéndole tener a éste por rey de Murcia y luchar contra los enemigos. En cuanto al comendador de Ricote, lo envió a entrevistarse con el maestre para "fer semblatment del castell de Ricote e de la Pena d'Oxoix ${ }^{58}$.

56 ACA, C, reg. 118, fols. 91v.-92r. Publicado por J. TORRES FONTES, Documentos del siglo XIII, núm. CXLVI y R. SAINZ DE LA MAZA, La Orden de Santiago, doc. 141.

57 ACA, c.r. Jaime II, caja 10, núm. 1351. Publicado por J. TORRES FONTES, Documentos del siglo XIII, núm. CXLVII (equivoca la signatura) y R. SAINZ DE LA MAZA, La Orden de Santiago, doc. 142.

58 ACA, c.r. Jaime $\mathrm{H}$, caja 95, núm. 11.611 ([1301], mayo, 27). 
Bernat de Sarrià mantuvo informado a Jaime II de estas negociaciones, el cual le contestó diciéndole que, a pesar de que le parecía muy bien que pusiese a los santiaguistas "en aquella millor guisa que pugats", sin embargo debía ordenar a éstos que, en caso de que Fernando IV acudiese personalmente al reino de Murcia, no deberían acogerle si no querían perder sus lugares ${ }^{59}$.

A primeros de julio el comendador de Ricote Juan Álvarez regresó de Castilla de verse con el maestre, no siendo sin embargo el resultado de la entrevista el que se había pretendido, ya que Juan Osores no sólo no le entregó la Peña de Ojós, sino que había dudado de que Jaime II hubiese mandado decir todo lo que el comendador le había expuesto de su parte. Por ello Bernat de Sarrià decidió enviarle nuevamente ante el maestre para pedirle por segunda vez la Peña de Ojós, así como un mandato a todos los lugares santiaguistas de Murcia de acatamiento a Jaime II. Además, tenemos constancia documental de que el procurador también entró en tratos con el comendador de Socovos Juan López, consiguiendo de él su adhesión a Jaime $\|^{60}$. Sin embargo, a pesar de este logro, Bernat de Sarrià no confiaba demasiado que las gestiones que estaba llevando a cabo para recuperar la fidelidad de los santiaguistas de Murcia lograsen el resultado deseado, y por ello pidió a Jaime II cartas de recomendación para secundar sus peticiones ante el maestre ${ }^{61}$, si bien una de ellas se cumplió por aquellos días: la entrega de Ojós que Juan Osores le hizo a través del comendador de Ricote Juan Álvarez.

Jaime $I I$ accedió inmediatamente a la petición del procurador, y el 19 de aquel mismo mes escribió tres cartas de recomendación. La primera de ellas iba dirigida a Juan López, comendador de Socovos, con la promesa de que haría cumplir todo lo que hubiese tratado con Bernat de Sarrià ${ }^{62}$, y las otras dos iban destinadas al maestre. Por la primera de ellas Jaime II le comunicaba que tendría por firmes todos los tratos que, para el buen estado del reino y de la Orden de Santiago, hiciese con Bernat de Sarrià, a quien debería dar crédito de lo que le diría de su parte ${ }^{63}$. La segunda contenía una promesa del rey aragonés al maestre: que cuando reinase la paz entre él y Castilla le devolvería a los castillos y lugares de Negra y de Peña de Ojós, así como todas las rentas de Negra y de la val de Ricote, asegurándole además guardar y proteger el patrimonio de la Orden como si fuese un bien personal ${ }^{64}$.

59 Las instrucciones que Bernat de Sarrià tenía que dar a los santiaguistas del reino de Murcia de parte de Jaime II eran las siguientes: «vos les declaretz que si don Ferrando, qui.s diu rey de Castella, venia personalment en regne de Múrcia, ne encara ses gens ne sos valedors, que nol.s acuylissen els dits locs, declarant a ells que sien certs que, si u faren, que nós pendriem los lochs que la Orde ha en nostre senyoria on que fossen ": ACA, $C$, reg. 118, fol. 112r. (1301, mayo, 27),

60 Con estas palabras comunicó Bernat de Sarrià al monarca aragonés la fidelidad del comendador de Socovos: «... yo e tractats alcuns feyts ab Johan Lopis, comanador de Socovos, el qual ha voluntat de vos servir e el qual... serà a servey vostre e a profit del regne...»; ACA, c.r. Jaime II, caja 152, núm. 825 ([1301], julio, 10)
61 Ibídem.
62 ACA, C, reg. 334 , fol. $30 \mathrm{v}$.
63 ACA, C, reg. 334, fol. 30r.
64 Apéndice, núm. 4. 
Tras estas negociaciones, que garantizaban de momento la fidelidad de los santiaguistas a cambio de las promesas que el monarca les hacía, un clima de buena relación se estableció entre aquellos y Jaime II, el cual, con el deseo de que se mantuviera, aconsejó a Bernat de Sarrià que las convocatorias de las huestes del reino de Murcia que estaba llevando a cabo no pusieran en guerra a los lugares de las Órdenes ${ }^{65}$. A este estado de buen entendimiento con la Orden de Santiago contribuyó en gran manera el comendador de Ricote Juan Álvarez, aragonés, y que como hemos dicho actuó de interlocutor ante el maestre, haciendo gala de una actitud completamente leal a la causa de Jaime II. Éste, a finales de septiembre, le agradeció los servicios que estaba prestando a Alfonso, rey de Castilla, y le animó a seguir con su actitud, ya que sirviendo al rey Alfonso, le servía a él mismo ${ }^{66}$.

$Y$ es que a Jaime II le interesaba mantener la adhesión de sus incondicionales, puesto que algunos ricoshombres de Aragón ya se habían desavenido de él y la inestabilidad en el reino de Murcia, a causa de la falta de soldados, la escasez de vianda en los castillos y las amenazas continuadas de ataques castellanos, empezaba a ser preocupante, pese a que durante el resto de aquel año se mantuvo una cierta calma militar, así como el buen entendimiento con los santiaguistas.

En efecto, a comienzos del año 1302 Jaime II y el comendador de Ricote, Juan Álvarez, prosiguiendo sus buenas relaciones, se escribieron y enviaron emisarios para tratar asuntos comunes ${ }^{67}$. Sin embargo, a finales de febrero, y por causas que desconocemos, dicho comendador desconfió de Jaime II al creer que estaba poniéndose de acuerdo con Castilla, recelo que transmitió al propio monarca. Éste, para disipar sus dudas y tranquilizarle, le escribió manifestándole lo equivocada que era su sospecha: «nos, adobo nenguno no avemos feyto con Castiella ni vos en tal temer, ante seet cierto que es nuestro entendimiento de perseverar e levar los feytos más enfortidament que nunca en ayudar al muy alto rey don Alfonso de Castiella e infant don Ferrando, su hermano, caros cormanos nuestros, en la demanda que han en Castiella». Por todo ello le instaba a servir a dichos rey e infante, de los cuales, y también de él mismo, recibiría como contrapartida "muyto bien e muyta mercé»"68.

No solamente el comendador de Ricote mantenía su lealtad a Jaime II, sino también el comendador de Aledo, Centón Ruiz, al que el monarca agradeció igualmente sus servicios a la causa de Alfonso de la Cerda ${ }^{69}$.

65 ACA, C, reg. 122, fol. 231r.-v (1301, agosto, 29) Cit. Mª.T. FERRER I MALLOL, Organització, p. 37.

66 «Sepades que entendiemos que vos servides e punyades servir en aquexas partes al muy noble don Alfonso, rey de Castielia, caro cormano nuestro, e gradezemos vos lo muyto, ond vos rogamos e vos dizimos que al dito rey puynnedes servir quanto podades, que serviendo a ell provides a nos e lo que bien avedes començado, levatlo a cabo adelant, que grant bien vos en verndrá»: ACA, C, reg. 119 , fol. 32r. (1301, septiembre, 29).

67 El 14 de febrero Jaime II escribió a Juan Álvarez, comendador de Ricote, pidiéndole diera crédito a su escudero Rodrigo de Biscarra, que acudía a su presencia para tratar algunos negocios: $A C A, C$, reg. 123 , fol. 5 r.

68 ACA, C, reg. 334, fol. 49r. (1302, febrero, 23).

69 ACA, C, reg. 334 , fol. $49 \mathrm{v}$. (1302, febrero, 23). 
El apoyo que Jaime II estaba recibiendo de los santiaguistas en aquellos momentos era realmente importante ante los rumores de que los castellanos se preparaban para entrar en el reino de Murcia durante el próximo verano ${ }^{70}$. El monarca pidió ayuda a sus súbditos, y también a todos los del reino de Castilla «que la boz e carrera del muy noble rey don Alfonso de Castiella querrán tomar ${ }^{71}$, destacando de nuevo en aquellos momentos los servicios que el comendador de Ricote dispensaba a Alfonso de Castilla y que Jaime II le agradeció una vez más ${ }^{72}$.

Los preparativos para una campaña militar prosiguieron durante los primeros meses de 1303, produciéndose el 3 de abril el nombramiento de Pere de Montagut en la procuración del reino de $\mathrm{Murcia}^{73}$, en substitución de Bernat de Sarrià, a quien le siguió confiando el asedio de Mula.

Por to que respecta a los santiaguistas, nos consta que Jaime II continuó protegiéndoles durante toda la primera mitad de aquel año, cursando el día 26 de mayo dos disposiciones a su favor: que en los lugares de la Orden de Santiago en Murcia no se exigieran las cenas, a no ser como se las exigían en época de los reyes de Castilla, y que el procurador y oficiales de Murcia no causasen daño alguno al valle de Ricote, Peña de Ojós, Negra y Cieza, a los que concedía su guiaje ${ }^{74}$. Sin embargo, estas disposiciones no iban a evitar que muy pronto las circunstancias políticas llevasen a los santiaguistas del reino de Murcia a retirar definitivamente su apoyo a Jaime II.

\section{LAS RELACIONES CON LA ORDEN DE SANTIAGO ENTRAN EN CRISIS}

En efecto, los rumores de un ataque castellano aumentaban y en septiembre Bernat de Sarrià informó a Jaime II que, según le habían dicho, Fernando IV de Castilla, personalmente o enviando una compañía, llegaría pronto para recibir el valle de Ricote y todos los demás castillos que las Ordenes tenían en el reino de Murcia ${ }^{75}$. Tal como hemos podido comprobar a través de la documentación, esta noticia coincidió, al igual como había sucedido a mediados de 1300 , con un cambio radical en la conducta de los santiaguistas de Murcia, los cuales, alentados por la anunciada ayuda castellana, decidieron retirar su apoyo a Jaime II. Este cambio de postura se vio favorecido, además, por el fallecimiento del comendador de Ricote Juan Álvarez, aragonés, y que tan buenos servicios le había prestado. Tanto su sucesor Juan López, como los comendadores de Cieza y Aledo, empezaron a causar al reino daños tan graves, que Jaime II no pudo por menos que denunciarlos al propio maestre con estas elocuentes pala-

70 Ante los rumores de los preparativos que se hacían en Castilla, Jaime Il ordenó a su procurador en Murcia Bernat de Sarrià pusiese guardas en los castillos: ACA, C, reg. 123, fol. 37v. (1302, marzo, 8).

71 ACA, C, reg. 123, fols. 102v.-103r. (1302, abril, 19).

72 ACA, C, reg. 123, fol. 103r. (1302, abril, 20).

73 Ma.T. FERRER, Organització $i$ defensa, doc. 28.

74 ACA, C, reg. 128, fol. 143v. (1303, mayo, 26).

75 ACA, c.r. Jaime II, caja 100, núm. 12.519. Publicado por A. GIMÉNEZ SOLER, Don Juan Manuel, Zaragoza, 1932, doc. LXXXII (parcial) y caja 101, núm. 12.552 ([1303], septiembre, 10). 
bras: «los comendadores qui tienen agora los castiellos de la Orden vuestra que son en el regno nuestro de Murcia, an feyto et fazen cada día muytas terrerías et daynos et agraviamientos a las nuestras gentes del dito regno, et vierne end por esto grant destorbo a nos et mal al dito regno ${ }^{76}$. Concretamente, sabemos que el comendador de Aledo Centón Ruiz y sus gentes, cambiando radicalmente el comportamiento que habían tenido, agraviaban a los de Lorca y daban cobijo en el castillo a almogávares y castellanos, que insidiaban y capturaban a los aragoneses ${ }^{77}$. Otro de los perjudicados por el comportamiento del comendador de Aledo fue Ramón de Mula, a quien sin ninguna razón quitó 80 yeguas y otras bestias que, junto con otros compañeros, sacaba de Castilla, dando muerte a alguno de ellos. Jaime II, quejoso de la actuación del comendador porque había cometido el robo «en deserviçio nuestro", rogó al maestre que le obligase a devolver lo sustraído y le castigase por ello ${ }^{78}$.

Jaime II, aprovechando la notificación que hacía al maestre Juan Osores de los males que los comendadores le estaban causando, le rogó encarecidamente que encomendara estos castillos a freires de Aragón, renovando su propuesta de que fuera el comendador de Montalbán, en aquel momento Artal de Huerta, quien los tuviese, lo que evitaría que se produjesen daños "ni a nos ni a nuestra tierra".

Antes de saber la respuesta del maestre y sin duda para ganarse su favor, Jaime II decidió restituir Negra, que a fines de 1301 había prometido devolver a la Orden cuando reinase la paz con Castilla, lo que todavía no había sucedido. Así pues en septiembre ordenó a Bernat de Sarrià, que como hemos comentado poseía este castillo por la donación que le había hecho en premio a sus servicios, que lo restituyese al comendador de Ricote Juan López ${ }^{79}$; sin embargo, al fallecer éste por aquellas fechas, el rey ordenó entonces lo entregara al comendador de Montalbán Artal de Huerta, no como a comendador, sino con carácter personal, con lo cual Negra seguía sin ser devuelta a la Orden ${ }^{80}$.

Conocemos la respuesta del maestre Juan Osores a las propuestas de Jaime II a través de una carta que le envió el 30 de diciembre ${ }^{81}$. A través de ella pedía al monarca que tuviera bajo su protección los bienes santiaguistas y le exigía que entregara el castillo de Negra al freire Miguel Pérez, que le enviaba con su carta. Además, como Jaime II, en contra de la política de alianza seguida años atrás con los moros de Ricote, les había aumentado los tributos, le pidió también que no hiciera ni consintiera hacer tuertos a sus vasallos de Ricote, los cuales nunca habían pechado por tener privile-

76 ACA, C, reg. 130, fol. 170r. (1303, octubre, 29). Publicado por R. SAINZ DE LA MAZA, La Orden de Santiago, doc. 156.

77 Jaime II ordenó al comendador que no consintiera los males que sus gentes estaban infiriendo a los de Lorca: ACA, C, reg. 129, fol. 107v. (1303, octubre, 3)

78 ACA, C, reg. 130, fol. 201r. (1303, diciembre, 1).

79 AHN, carp. 293, núm. 4. Publicado por J. TORRES FONTES, Codom, II, doc. 151.

80 ACA, C, reg. 201, fol. 56v. Publicado por R. SAINZ DE LA MAZA, La Orden de Santiago, doc. 157. El 1 de noviembre Jaime II notificó al comendador de Montalbán Artal de Huerta los ruegos que había hecho al maestre de que le encomendara los castillos de la Orden en el reino de Murcia, así como su decisión de que el castillo de Negra pasase a sus manos: ACA, C, reg. 130, fol. 173r. Publicado por R. SAINZ DE LA MAZA, La Orden de Santiago, doc. 158.

81 Apéndice, núm. 5. 
gios y franquicias. Por último, se excusaba por no poder acudir al reino de Murcia, como era su intención, para verse con el procurador y tratar del comportamiento de sus vasallos, ya que debía acudir rápidamente ante el rey de Portugal que le había convocado, pero le prometía acudir en breve y le aseguraba que todos los lugares de la Orden que estaban bajo su dominio no le harían daño. Con estas palabras el maestre daba su negativa a la propuesta de Jaime II de colocar los castillos santiaguistas de Murcia bajo la dirección de la Encomienda de Montalbán.

Esta carta era ya conocida, pero no así la contestación que Jaime II dio al maestre el 30 de marzo de 1304 y que he tenido la fortuna de encontrar. En primer lugar, a su petición de tener bajo su guarda todo lo que la Orden tenía en su tierra, el monarca le declaraba que ésta había sido siempre su intención, siempre y cuando los santiaguistas actuasen "como fazer deven" y no dañasen su tierra. En cuanto al castillo de Negra, el monarca le decía que en aquel momento no se lo podía entregar, pero que cuando acudiese a Murcia "faremos a aquello que será bien»82. A la tercera petición o advertencia sobre las pechas de sus vasallos, Jaime II manifestaba que de la misma forma que las tenía de las otras Órdenes, las quería tener también de Santiago, a no ser que la Orden de Santiago poseyera privilegios, en cuyo caso le pedía se los mostrase para observarlos. Por último a la afirmación del maestre de que nunca había dejado de servirle y que de sus lugares nunca vendría mal a su tierra, la respuesta de Jaime II contenía una buena dosis de ironía. El rey le rogaba, «pues tan bien lo dezides», que ordenase a sus vasallos del reino de Murcia se comportasen de tal forma que él se sintiera correspondido, y lo sería si él, tal como le había prometido, acudiese al reino de Murcia «e fiziéssedes adobar aquello que Centon Ruiz (comendador de Aledo) e otros han feyto cuentra nos e nuestra tierra e nuestros vassallos" ${ }^{83}$. Con estas palabras Jaime II manifestaba claramente al maestre que a no ser que se presentase y arreglase la situación que sus vasallos estaban provocando en el reino de Murcia, sus argumentos no tenían ni valor ni fiabilidad para él.

Y era lógico, por otra parte, que una vez más Jaime II desconfiara del maestre, ya que por aquel entonces no había cumplido los ruegos que le había hecho de obligar al comendador de Aledo a restituir a Ramón de Mula todo lo sustraído, lo que ocasionó que el monarca ordenase la entrega a éste de la heredad llamada Algorfa, situada en el término de Orihuela y perteneciente a la Orden, para que pudiera explotarla hasta que el comendador le hiciera restitución de lo robado ${ }^{84}$; sin embargo el rey desconocía

82 Unos días antes el freire santiaguista Miguel Pérez de Guasillo pidió a Jaime Il le entregase el lugar de Negra, puesto que el maestre quería "que yo por él lo reçiba»: ACA, c.r. Jaime II, caja 16, núm. 2135 (1304, marzo, 16).

83 Apéndice, núm. 6. También aquel mismo día Jaime ll escribió a Don Juan Manuel, en respuesta a los ruegos que le había hecho a favor de la Orden de Santiago y sus freires. El monarca le contestó diciéndole que, teniendo muy en cuenta sus ruegos, estaba protegiendo el patrimonio de la Orden, si bien que ría que supiera que «en el regno de Murcia algunos freyres e vassallos de la Orden han feyto en deservicio nuestro": ACA, C, reg. 235, fol. 44r. (1304, marzo, 30).

84 La orden de Jaime II a su procurador en Murcia Pere de Montagut de entregar Algorfa a Ramón de Mula fue dada el 15 de febrero: ACA, C, reg. 131, fols. 72v.-73r., orden que le cursó de nuevo el 1 de abril: c.r. Jaime II, caja 18, núm. 2322. 


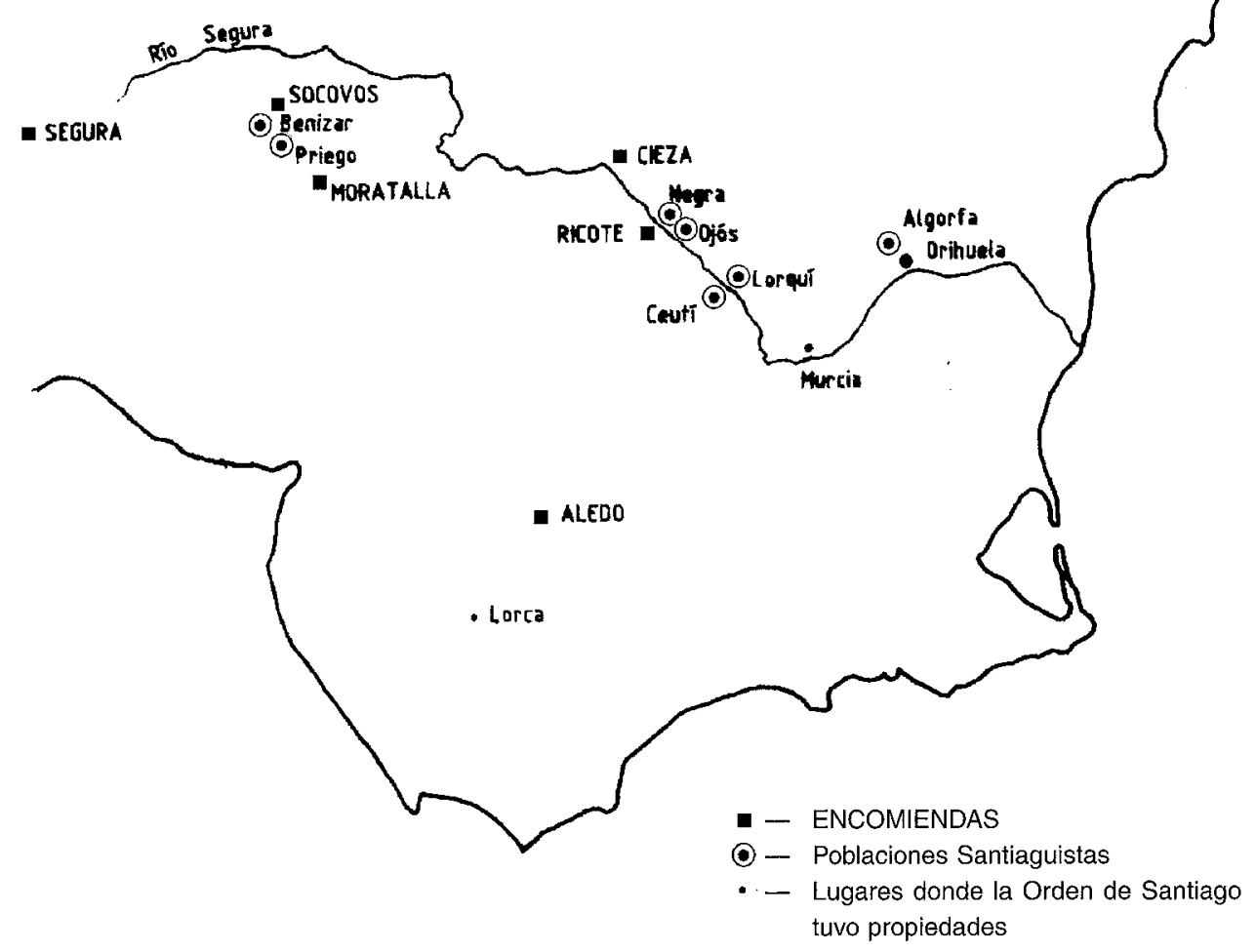

Lugares santiaguistas implicados en la ocupación aragonesa del Reino de Murcia (1296-1304)

que este lugar había sido concedido a violario por el maestre a Juan Muntaner, el cual, lógicamente, protestó, disponiendo entonces el rey la restitución de Algorfa a su propietario y la entrega a Ramón de Mula de otros bienes de Santiago en compensación ${ }^{85}$. Esta indemnización siguió perjudicando el patrimonio santiaguista en el reino de Murcia, por lo que no resulta extraño que aquel año el maestre Juan Osores solicitase a Fernando IV de Castilla poder hacer uso del privilegio que el papa había concedido a la Orden de Santiago en 1287, de predicar y recaudar cruzada para la defensa de varios castillos fronterizos, citándose, entre otros, los de Aledo, Ricote, Peña y Moratalla ${ }^{86}$.

85 ACA, C, reg. 132, fol. 149r.-v. El procurador del reino de Murcia Pere de Montagut sugirió al rey se compensara a Ramón de Mula con bienes de la Orden de Santiago en Lorca, que eran de la encomienda de Aledo y Moratalıa: ACA, c.r. Jaime II, caja 18, núm. 2322 (1304, abril, 4). Juan Muntaner y su mujer doña Alamanda habían recibido por concesión del maestre Juan Osores todo lo que la Orden poseía en Orihuela y en la Algorfa, y ellos, a su vez, donaron a la Orden cuanto poseían en Lorca y su término: AHN, OO.MM. Uclés, carp. 50, vol. I, núm. 9.

86 Ver la bula papa en B. CHAVES, Apuntamiento legal sobre el dominio solar de la Orden de Santiago en todos sus pueblos, El Albir, reimpr. 1975, Barcelona, pp. 194v-195r. Cit. M. RODRÍGUEZ LLOPIS, Repoblación, p.12. El 1 de julio de 1303 Fernando IV de Castilla concedió al maestre Juan 
Vemos, pues, que la inestabilidad que desde comienzos de 1303 estaba ocasionando en el reino de Murcia el señorío de la Orden de Santiago era una realidad, como también la que produjo la intervención de la compañía de jinetes del noble marroquí Alabbàs ben Rahu, a quien Jaime ll el 22 de diciembre del año anterior había encomendado la tarea de hostilizar al enemigo. Las condiciones del establecimiento no sólo eran onerosas para el monarca, sino que hicieron empeorar aún más las relaciones con los santiaguistas, ya que el castillo de Negra y los lugares de Ceutí y Lorquí se entregaron a estos africanos para su establecimiento. Las consecuencias no tardaron en hacerse notar, ya que en abril de 1304 y a raíz de una expedición que ben Rahu iba a efectuar a Castilla, los de Cieza y Aledo avisaron a los castellanos de las intenciones del africano, al que ocasionaron, en especial Cieza, numerosos daños que el propio ben Rahu describió a Jaime $\|^{87}$.

La situación creada, empeorada por el deterioro de las relaciones con el reino de Granada que había firmado la paz con Castilla, la falta de recursos por ambas partes, y el cansancio condujeron a la paz que todos deseaban y que la llegada de la mayoría de edad de Fernando IV iba a facilitar. La sentencia de Torrellas, firmada el 8 de agosto de 1304 decidió la división del reino de Murcia, quedando para Castilla la parte meridional y su capital y para la corona catalano-aragonesa las comarcas septentrionales, que al cabo de pocos años se anexionarían al reino de Valencia.

Precisamente, tras la sentencia de Torrellas, iban a ser dos santiaguistas, el maestre Juan Osores y el comendador de Montalbán Artal de Huerta, quienes actuarían de intermediarios para la devolución de los lugares del reino de Murcia ${ }^{88}$. Artal de Huerta acudió a Murcia el 11 de noviembre para recibir del maestre de santiago, en nombre del rey de Castilla, los castillos y lugares que éste debía entregar a Aragón. Y el maestre Juan Osores, por su parte, fue recibiendo, entre los días 16 y 19 de noviembre los lugares que Jaime Il debía devolver a Castilla, recuperando finalmente para su Orden el castillo y villa de Negra tantas veces reclamado ${ }^{89}$.

Así terminó aquel capítulo de la historia del reino de Murcia, ocupado temporalmente por Aragón, mediante la firma de una paz que las palabras de pleitesía que dirigió Jaime II a su antiguo enemigo Fernando IV de Castilla dejaba sellada: «os prometo vos amar e de querer vuestra honrra e vuestra pro, e de ser amigo de vuestros amigos et enemigo de vuestros enemigos...

Osores, a petición suya, poder recaudar la cruzada. Ver A. BENAVIDES, Memorias de Fernando IV de Castilla, Madrid, 1860, vol. II, doc. CCXXXV.

87 «... porque senyaladament nos fisieron danno y estorvo los de Cieça, en que nos negaron tres cabeças de vacas que les avíamos acomendadas e nunca las podremos aver. Et más, corrieron nos a Negra e no nos podieron façer más danyo, salvo que nos crebantaron ochaenta e tres colmenas e levaron nos una gran pieça de trapo de lienços... »: ACA; c.r. Jaime II, caja 92, núm. 11.186.

88 El 10 de octubre el maestre Juan Osores comunicó a Jaime II que el rey de Castilla le enviaba al reino de Murcia para hacer cumplir las entregas de lugares que ambos debían efectuar. De nuevo, le reiteró su petición de que le devolviera el lugar de Negra: ACA, c.r. Jaime II, caja 17, núm. 2204.

89 Juan TORRES FONTES, Documentos del siglo XIII, docs. CLVI-CLXVII.

90 ACA, c.r. Jaime II, caja 125, núm. 1815. (s.f.) [1304]. 


\section{APÉNDICE DOCUMENTAL}

1296, junio, 11. Murcia.

Fernando Pérez, comendador de Ricote, y Juan Martínez, comendador de Cieza, juran homenaje a Jaime /l por sus respectivos castillos, así como por los de Aledo, Negra, Ojós y demás lugares que tienen en el reino de Murcia.

ACA, c.r. Jaime II, caja 152, núm. 834.

Ferrandus Petri, comendator de Ricoto, Johannes Martini, comendator de Cessa.

In tertio idus iunii, anno Domini $\mathrm{M}^{\circ} \mathrm{CC}^{\circ} \mathrm{XC}^{\circ} \mathrm{VI}^{\circ}$, in civitate Murcie, in domo domini regis, Ferrandus Petri, comendator de Ricoto, Johannes Martini, comendator de Cessa, iuraverunt domino regi tenere dicta castra et alia loca que habent in regno Murcie pro dicto domino rege, e facere pro domino rege predicto de dictis castris, et de castris de Cessa, de Aledo, de Negra et de Penna d'Oxuix, et etiam de aliis locis que ipsi habent in regno Murcie, facere pacem et guerram et omnia alia que facere tenebantur aliis dominis regni predicti Murcie.

(En el margen inferior) Cessa, Aledo, Negra, La Penna de Sux.

\section{2}

1297, junio, 27. Asedio de Lorca.

Jaime II ruega al maestre de Santiago Juan Osores permita a Fernando Pérez, comendador de Ricote, de quien alaba sus virtudes, seguir al frente de esta encomienda, ya que se ha enterado de que quiere destituirle.

ACA, C, reg. 253 , fol. $27 \mathrm{v}$.

Al noble e amado don Johan Osores, maestro de la Horden de la cavallería de Sant Jayme et cetera.

Entendiemos que agora avíades çitado a Ferrant Péreç, comendador de la val de Ricot, a capítol e que allí le avíades tuelta la comanda de Ricot e que la queríades dar a otro. E como el dito Ferrant Pérez sia homne bueno e en qui muyto podría homne fiar, e él la su comanda aya tenido bien e lealment assí que danno ni menoscabo no a venído por él al regno nuestro de Murcia, rogamos vos que por amor de nos embiedes al dito Ferrant Pérez por comendador de Ricot assí como la tenía, et si por ventura por cosas que.I fiçiesse contra la Orden lo avíades a mudar de la dita comanda, que consintades que la tenga el dito Ferrant Pérez entro que nos ayades certifficado a qui 
tenredes por bien de comendarla, que se faga con nuestra voluntat porque nos no end ayamos a aver sospeyta, e gradecer vos lo hemos muyto.

Dada en el sitio del castiello de Lorca, III días por andar del mes de junio et cetera.

Petrus Martini, mandato Guillermi Durffortis.

[1300], diciembre, 3. Orxeta.

Jaime II a Juan Osores, maestre de Santiago, acusando recibo de su carta en la que se extrañaba de que Bernat de Sarrià hubiese obligado a los castillos y lugares que la Orden tiene en Murcia a luchar contra los enemigos. El rey le responde que no se ha convocado a los freires y religiosos de la Orden, sinó únicamente a los legos y pobladores de los lugares. Bajo los mismos términos al comendador de Ricote.

ACA, C, reg. 254 , fol. 23 r.-v.

Don Jayme et cetera, al honrado don Johan Osores, maestro de la Orden de la cavallería de Sant Yago, salut e dilección.

Recibiemos vuestra carta que agora nos embiastes en razón de los castiellos e lugares que la vuestra Orden ha en el regno de Murcia, los quales requerió Bernat de Serrián, amado conseyllero nuestro, que fiziesces guerra a nuestros enemigos. Ond nos, entendido esto e todo lo al que en la dita carta vuestra nos embiastes dezir, vos respondemos que los reyes del regno de Murcia, antecessores nuestros, quando dieron los logares sobreditos a la vuestra Orden, si retovieron fieldat et paç et guerra, et nos, qui somos rey e sennor del reygno sobredito de Murcia, ayamos e devemos y aver aquella misma fieldat, paç e guerra que los otros reyes y avían. Porque non vos maravilledes en la guerra que avemos con Castiella nos queremos ayudar de los ditos logares, no empero que nos, los freyres ni los religiosos qui son de la dita Orden en los ditos logares mandemos ni fagamos yr en uest ni fer guerra, salvo de los ditos logares e de los homnes legos de aquellos, de los quales nos devemos ayudar et queremos contra nuestros enemigos.

Datum in Orcheta, sub sigillo nostro secreto, $11^{\circ}$ nonas decembris, anno predicto $\left[\mathrm{M}^{\circ} \mathrm{CCC}\right]$.

Similis fuit facta comendatori de Ricot, verbis competenter mutatis.

1301, julio, 19. Lleida.

Jaime II promete a Juan Osores, maestre de Santiago, que en cuanto reine la paz entre él y Castilla le devolverá el castillo de Negra, que concedió al procurador del reino de Murcia Bernat de Sarrià, y el de Ojós, que el propio maestre ha mandado 
entregar a dicho Bernat por medio del comendador de Ricote Juan Alvarez. También le promete las rentas de Negra y del valle de Ricote, y tener en paz estos lugares.

ACA, C, reg. 334 , fol. 30 r.

Sepan todos quantos esta carta verán que nos, don Jayme, por la gracia de Dios rey de Aragón, de Valencia e de Murcia, conde de Barcelona, prometemos a vos, honrado e religioso don Johan Osorez, maestro de la Orden de la cavallería de Sant Yago, absent, assí como si fuéssedes present, que nos rendremos e livraremos a vos, o a qualquier que será maestro en aquell tiempo, o a los frayres qui por vos o por el maestro qui será en aquel tiempo serán enbiados a reçebir, los castiellos e logares de Negra e de la Peyna de Xoys en aquel tiempo que sea paç entre nos e aquel qui regnará en Castiella, el qual castiello de Negra tiene por nos el amado conseyllero nuestro en Bernat de Serrián, procurador del regno de Murcia, el qual castiello de la Peyna de Xoys vos avedes mandado livrar al dito en Bernat de Serrián por Johan Alvareç, comandador de Ricot. Aún vos prometemos que nos vos mandaremos dar luego e responder de todas las rendas del dito logar de Negra e de la vayl de Ricote tener en patz aquellos logares. Aún vos prometemos que guardaremos todos los logares e bienes e cosas vuestras e de la Orden que son en nuestra senyoría bien, assí como las nuestras cosas propias.

En testimonio de la qual cosa, fiziemos fer esta carta e seellar con nuestro siello colgado.

Dada en Lérida, XIX días andados del mes de julio, en el ayno de Nuestro Senyor de mil e CCC e uno.

Petrus Martin, mandato regio.

1303, diciembre, 30. El Corral.

Juan Osores, maestre de Santiago, a Jaime II, pidiéndole proteja el patrimonio de la Orden en Murcia, le devuelva Negra y no agravie a sus vasallos moros de Ricote contra los privilegios que poseen. El maestre se escusa por no ir a Murcia, prometiendo acudir en breve.

ACA, c.r. Jaime II, caja, 15, núm. 1905.

Cf. doc. 6.

Al muy alto e poderoso sennyor don Jayme, por la gracia de Dios rey de Aragón, de Valencia, Murcia e comte de Barçalonna e de la sancta eglesia de Roma almirán e capital general. Nos, Johan Ossoreç, por la merçé de Dios mayestre de la cavallería de Santiago, besando las vuestras manos com[endamos nos] en vuestra gracia, como de sennyor al qual deseyamos servir. 
Por [vuestra] reyal magestat se conviene fazer ayuda e socorso a las Ordenes e tenerlas en comanda e guiage e non fazerles injuria nin consentir fazer. A vos, sennyor, enviamos mercé pedir que senya la vuestra mercé que todo lo que yes en la vuestra tierra e sennyoría de la nuestra Orden, querades aver en vuestra comanda. Otrosí, sennyor, como vos otras vegadas nos anyades prometido de render el nuestro lugar de Negra, que senya la vuestra mercé que nos lo querades e mandades entregar a este nuestro freyle Miguel Péreç, que a vos enviamos con esta nuestra carta. Otrosí, sennyor, que senya la vuestra mercé que non querades [...] ar nin consintades fazer tuertos nin fuerças a los nuestros vasallos moros de Ricot, como nunca costumpnaron de pechar por razón que los avemos quitos por privilegios e franquezas, mas senya la vuestra mercé que querades sobreser e dexar estas demandas que nos, sennyor, de vos atendemos valer más e aver franquezas e ser mantenidos en aquellas, que non valer menos e ser inniuriados por vos, la qual cosa se conviene fazer a la reyal magestat, e así fuemos mantenidos, sennyor, todos tiempos por los vuestros antecessores, ca, sennyor, nunca fuemos nos en vuestro deservicio. Demás, sennyor, seet cierto que de los lugares que nos avemos en la vuestra senyoría nonca venrá dannyo ni enojo a vos nin a la vuestra tierra, ante avemos mandado e mandamos que senyan a vuestro servicio. Demás, sennyor, sabet que nuestra voluntat era por yr al regnado de Murcia e veernos con vuestro procurador e por darvos dreynto de los nuestros, siquiere freyles, siquiere seglares, e tanbién de Centón como de los otros, mas del rey <de> Portugal oviemos presuradamientre mandado e ymos nos pora él, mas fiamos por Dios que en breu será nuestra tornada e nos yremos pora Murcia por veernos con vuestro procurador e por fazer todas aquellas cosas que nos y fazer devamos.

Dada en El Corral, trinta días de desembre, era de mill e CCC e XLI annos.

1304, marzo, 30. Calatayud.

Jaime II a Juan Osores, maestre de Santiago, acusando recibo de su carta y dándole respuesta a sus peticiones y declaraciones. Entre otras cosas, le pide que acuda a Murcia y enmiende el mal comportamiento que están teniendo sus vasallos en este reino, en especial Centón Ruiz, [comendador de Aledo].

ACA, C, reg. 235 , fols. $43 v .-44 r$.

Cf. doc. 5.

Don Jayme et cetera, al honrrado e religioso varón don Johan Osores, maestro de la cavallería de Sant Yhago, salut e dilección.

Recibiemos vuestra carta que agora nos enviastes e entendiemos muy bien quanto en ella era contenido, a les quales vos respondemos. E primero, a aquello que nos demandastes que queriéssemos aver en nuestra comienda todo lo que la vuestra Orden ha en nuestra tierra, que nos, segunt que pertenexe a nuestra dignidat, queremos aver 
en nuestra comanda et en nuestra protección las Ordenes e lures bienes, las Ordenes catando a nos como fazer deven, e somos ciertos que los officiales de nuestra tierra, hon algo ha de fazer la Orden, vos catarán esto, si de los vuestros lugares e vassallos e tierras non salle mal ni danyo a la nuestra tierra.

Quanto al castiello de Negra, vos respondemos, que assí d'este lugar assí como de otros, aviamos feyto ordinación alguna por buen estamiento del regno de Murcia, por razón de la qual ordinación non podemos agora fazer livrar el castiello segunt que demandantes, mas encerca, si Dios quisiere, nos seremos en el regno de Murcia e estonce faremos hi aquello que será bien.

A lo al de las pechas de los vuestros vassallos, tenemos nos que assí como de las otras Ordenes avemos, nos mayorment por al deffendimiento del dito regno, que assí podamos aver d'ellos; mas si la Orden ha privilegios sobre esto, fazet nos los mostrar et nos observar vos los emos, assí como fazer devemos. Queremos empero que sepades que nos a los vuestros vassallos ni a los moros de Ricot non queremos ni consentiríamos que les fuesse feyto tuerto ninguno ni fuerça, ellos no faziendo porqué.

Quanto a aquello que nos enviastes dezir que nunqua fuestes en nuestro deservicio e que de los lugares que vos avedes en nuestro senyorío nunqua vendrá mal ni danyo a nuestra tierra, es cosa guisada que no se faga, e si d'otra guisa se fazía, non semellaría vuestro ni de la Orden. E pues tan bien lo dezides, rogamos vos que ordenedes de tal manera que los vassallos e freyres vuestros, specialmente del regno de Murcia, sean en tal manera ordenados enca nos e los nuestros officiales e nuestra tierra, que nos devamos seer pagados d'ellos, e seríamos pagados que vos, segunt que en la vuestra carta se contiene, viniéssedes al regno de Murcia e fiziéssedes adobar aquello que Centón Roiç e otros han feyto cuentra nos e nuestra tierra e nuestros vasallos.

Dada en Calataiubi, dos días en la exida del mes de março en el anno de Nuestro Senyor de mil trezientos e quatro. 